\title{
A comparison of the allometric growth in Uca leptodactyla (Crustacea: Brachyura: Ocypodidae) from two subtropical estuaries
}

\author{
Rosana Carina Flores Cardoso and Maria Lucia Negreiros-Fransozo* \\ NEBECG (Group of Studies on Crustacean Biology, Ecology and Culture), Departamento de Zoologia-IBB-C.P. 510-UNESP \\ 18618-000, Botucatu, SP, Brasil. *Corresponding author, e-mail: mlnf@ibb.unesp.br
}

\begin{abstract}
The allometric growth of Uca leptodactyla from two distinct subtropical estuaries on the Brazilian coast was evaluated concerning its growth pattern and size at onset of sexual maturity. Females attained maturity at similar sizes in both sites (4.1 $\mathrm{mm}$ of carapace length in Indaiá and $4.2 \mathrm{~mm}$ in Ubatumirim), while males differed slightly. They reached the size at sexual maturity of $5.3 \mathrm{~mm}$ of carapace length in Indaiá and $4.6 \mathrm{~mm}$ in Ubatumirim. Growth pattern is usually similar among crabs from distinct sites while size at sexual maturity is frequently different. However, in the case of $U$. leptodactyla it did not occur, probably due to the strong habitat similarity and intrinsic features of this species.
\end{abstract}

\section{INTRODUCTION}

A remarkable sexual dimorphism in crabs can be found among the representatives of the genus Uca Leach, 1814. Therein, females present both chelipeds small and symmetric, while males exhibit one cheliped (on the right or left side) enlarged and morphologically distinct from the one at the opposite side. Such major cheliped is used during agonistic and cohort displays, contributing to reproduction success and territory defence (Christy \& Salmon, 1984).

The adult size and the size at sexual maturity of certain crab species can be influenced by some environmental factors, such as substratum, availability and quality of food, salinity, tide exposition and the presence of other animals (von Hagen, 1987).

The relative growth and maturity on fiddler crabs have been extensively studied (Miller, 1973; von Hagen, 1987). More recently, intra-specific comparative studies have been performed by Negreiros-Fransozo et al. (2003) and Benetti \& Negreiros-Fransozo (2004). These authors have found differences in the largest sizes attained by crabs, in the growth pattern, and in the size at onset of sexual maturity of fiddler crabs. They have also inferred that information is associated with habitat features.

The fiddler crab Uca leptodactyla Rathbun, 1898 is a small ocypodid species that occurs in sandy environments with seawater influence, usually flooded by high tide. It can be found at mangroves edges, large bays, or even at islands in open sea. Specimens of $U$. leptodactyla from two estuarine areas were compared with reference to their growth patterns and size at onset of sexual maturity.

\section{MATERIALS AND METHODS}

\section{Studied sites}

The estuaries are located at the northern coast of São Paulo State and they are climatically characterized as sub-tropical regions: Indaiá river $\left(23^{\circ} 24^{\prime} 57^{\prime \prime} \mathrm{S}\right.$ and $\left.45^{\circ} 03^{\prime} 12^{\prime \prime} \mathrm{W}\right)$ and Ubatumirim river $\left(23^{\circ} 20^{\prime} 17^{\prime \prime} \mathrm{S}\right.$ and $\left.44^{\circ} 53^{\prime} 02^{\prime \prime} \mathrm{W}\right)$. These rivers do not have any connection which prevents adult crab migrations.

\section{Sampling}

Fiddler crabs were collected from May 2001 to April 2002, during low tide periods, in sand banks located at the mouth of the rivers Indaiá and Ubatumirim. Crabs were manually captured by two people for a period of 20 min each.

Substratum samples were taken to determine their grain composition and organic matter content. Sediment samples were maintained at $500^{\circ} \mathrm{C}$ for three hours. Their initial and final weights were registered. The organic matter content was obtained by the difference between the initial weight of the sediment and its ash-free weight, which was transformed in percentage. All values obtained were compared by analysis of variance (ANOVA); $\alpha=0.05$ (Zar, 1996). The sediment was submitted to the differential sieving and the percentage of fractions obtained was classified according to the diameter of the grain in millimetres $(\mathrm{mm})$ as follows: gravel $>2.0 \mathrm{~mm}$; very coarse sand $1.0-2.0 \mathrm{~mm}$; coarse sand $0.5-1.0 \mathrm{~mm}$; medium sand $0.25-0.5 \mathrm{~mm}$; fine sand $0.125-0.25 \mathrm{~mm}$; very fine sand $0.0625-0.125 \mathrm{~mm}$ and silt + clay $<0.0625 \mathrm{~mm}$.

\section{Crab analysis}

Crab identification was provided by Dr Gustavo A.S. Melo from the Museu de Zoologia da Universidade de São Paulo (MZUSP). All specimens were measured and sexed under a stereoscope provided with a camera lucida. Only crabs in intermoult stage with complete appendages were used in this study. The measured dimensions were the following: carapace width and length ( CW and CL); abdominal width (AW) and the 
Table 1. Mean percentages of organic matter in each site. The comparisons were performed between seasons within each site.

\begin{tabular}{lcc}
\hline & \multicolumn{2}{c}{ Sites } \\
\cline { 2 - 3 } Seasons & Indaiá & Ubatumirim \\
\hline Autumn & $14.62 \pm 0.66 \mathrm{~B}$ & $16.11 \pm 1.21 \mathrm{ab}$ \\
Winter & $17.59 \pm 0.16 \mathrm{~A}$ & $16.46 \pm 1.58 \mathrm{a}$ \\
Spring & $17.16 \pm 0.48 \mathrm{~A}$ & $18.33 \pm 0.82 \mathrm{a}$ \\
Summer & $15.31 \pm 1.66 \mathrm{~B}$ & $14.32 \pm 0.91 \mathrm{~b}$ \\
\hline
\end{tabular}

Upper case letters compare Indaiá data and lower case compare Ubatumirim data. Value with at least one same letter in common did not differ statistically (ANOVA, $P<0.05$ ).

cheliped propodus length (PL), the right for females and the major for males.

In this analysis, 345 specimens of Uca leptodactyla (186 males and 159 females) were utilized from the Indaiá estuary and 411 specimens (224 males and 187 females) from Ubatumirim. The allometric equation $\mathrm{Y}=a \mathrm{X}^{b}$ (Huxley, 1950) was used to evaluate the growth pattern and the Mature I software (Somerton, 1980) was adopted to achieve the size at onset of sexual maturity for crabs. This procedure was performed because this software is commonly used when maturity occurs in an interval of size in which the straight lines of juveniles and adults are overcoming.
The CL was used as independent variable, because it is a dimension that shows minor variations among those related to the sexual maturity changes in $U$. leptodactyla. The other dimensions (CW, PL and AW) were considered as dependent variables.

The allometric constant ' $b$ ' was tested by $t$-test (Ho; $b=1)$ at $\alpha=0.05$ and the slope of the straight lines (between juveniles and adults or between two sites) was compared by analysis of covariance (ANCOVA); $\alpha=0.05$ (Zar, 1996).

\section{RESULTS}

The sediment was composed mainly of very fine and fine sand, respectively in Indaiá and Ubatumirim, and both showed a moderated selection degree. The higher percentages of sediment organic matter content in Indaiá mangrove were obtained during winter and spring, while for Ubatumirim they occurred in autumn, winter and spring (ANOVA, $P<0.05$ ) (Table 1). No significant differences were found between both sites, when compared the same seasons ( $t$-test, $P<0.05$ ).

The size-range of the fiddler crab was very similar within the sites: from 2.3 to $7.4 \mathrm{~mm}$ of $\mathrm{CL}(5.0 \pm 1.29 \mathrm{~mm})$ for crabs from Indaiá and from 2.2 to $7.5 \mathrm{~mm}$ of CL $(5.1 \pm 1.17 \mathrm{~mm})$ for crabs from Ubatumirim.

The relationships obtained for the relative growth in Uca leptodactyla are presented in Table 2. Significant statistical differences were found in some equations (ANCOVA;

Table 2. Uca leptodactyla. Results of the regression analysis of the morphometric data, where carapace lenght (CL) is an independent variable.

\begin{tabular}{|c|c|c|c|c|c|c|c|c|}
\hline \multirow[b]{2}{*}{ Site } & \multirow[b]{2}{*}{ Variable } & \multirow[b]{2}{*}{ Category } & \multirow[b]{2}{*}{$\mathrm{N}$} & \multicolumn{2}{|c|}{ Power function $\left(\mathrm{Y}=\mathrm{a} \mathrm{X}^{\mathrm{b}}\right)$} & \multirow[b]{2}{*}{$r^{2}$} & \multirow[b]{2}{*}{$t(\mathrm{~b}=\mathrm{l})$} & \multirow[b]{2}{*}{ Allometry } \\
\hline & & & & $a$ & $b$ & & & \\
\hline \multirow[t]{12}{*}{ Indaiá } & \multirow[t]{4}{*}{ CW } & $\mathrm{JM}$ & 104 & 1.260 & 1.18 & 0.98 & $10.03 *$ & + \\
\hline & & $\mathrm{AM}$ & 82 & 2.019 & 0.91 & 0.86 & $2.00 *$ & - \\
\hline & & JF & 47 & 1.357 & 1.08 & 0.92 & 1.83 & 0 \\
\hline & & $\mathrm{AF}$ & 112 & 1.596 & 1.00 & 0.91 & 0.06 & 0 \\
\hline & \multirow[t]{4}{*}{ AW } & $\mathrm{JM}$ & 102 & 0.367 & 1.15 & 0.93 & $4.84^{*}$ & + \\
\hline & & $\mathrm{AM}$ & 77 & 0.609 & 0.85 & 0.72 & $2.52 *$ & - \\
\hline & & JF & 47 & 0.157 & 1.99 & 0.83 & $7.59 *$ & + \\
\hline & & $\mathrm{AF}$ & 112 & 0.309 & 1.60 & 0.89 & $11.10^{*}$ & + \\
\hline & \multirow[t]{4}{*}{ PL } & $\mathrm{JM}$ & 105 & 0.181 & 2.68 & 0.92 & $22.28 *$ & + \\
\hline & & $\mathrm{AM}$ & 83 & 1.619 & 1.40 & 0.72 & $4.12 *$ & + \\
\hline & & $\mathrm{JF}(\mathrm{ns})$ & 47 & 0.570 & 1.04 & 0.80 & 0.53 & 0 \\
\hline & & $\mathrm{AF}(\mathrm{ns})$ & 112 & 0.614 & 1.00 & 0.82 & 0.09 & 0 \\
\hline \multirow[t]{12}{*}{ Ubatumirim } & \multirow[t]{4}{*}{ CW } & JM & 65 & 1.300 & 1.18 & 0.91 & $3.84 *$ & + \\
\hline & & $\mathrm{AM}$ & 159 & 2.045 & 0.88 & 0.80 & $3.15 *$ & - \\
\hline & & JF & 46 & 1.773 & 0.93 & 0.82 & 1.14 & 0 \\
\hline & & $\mathrm{AF}$ & 141 & 2.061 & 0.87 & 0.91 & $5.61 *$ & - \\
\hline & \multirow[t]{4}{*}{ AW } & $\mathrm{JM}$ & 46 & 0.283 & 1.36 & 0.94 & $6.95 *$ & + \\
\hline & & $\mathrm{AM}$ & 121 & 0.463 & 1.00 & 0.86 & 0.10 & 0 \\
\hline & & JF & 47 & 0.298 & 1.63 & 0.78 & $4.88 *$ & + \\
\hline & & $\mathrm{AF}$ & 158 & 0.759 & 1.12 & 0.81 & $2.71 *$ & + \\
\hline & \multirow[t]{4}{*}{ PL } & $\mathrm{JM}$ & 62 & 0.363 & 2.20 & 0.87 & $10.88^{*}$ & + \\
\hline & & $\mathrm{AM}$ & 151 & 0.821 & 1.72 & 0.73 & $8.35^{*}$ & + \\
\hline & & JF & 42 & 0.622 & 0.98 & 0.88 & 0.28 & 0 \\
\hline & & $\mathrm{AF}$ & 156 & 0.807 & 0.84 & 0.81 & $4.76 *$ & - \\
\hline
\end{tabular}

*, significative by Student's $t$-test $(P<0.05)$; CW, carapace width; AW, abdominal width; PL, propodus length; JM, juvenile male; AM, adult male; JF, juvenile female; AF, adult female; N, number of crabs; 0 , isometry; + and -, alometry and (ns), ANCOVA, $\alpha=0.05$. 
$\alpha=0.05)$ comparing the values of regressions between the studied areas. Exceptions were detected in the relationships PL vs GL and AW vs CL (males).

During the fiddler crab ontogeny the juvenile growth differs from adult with respect to the allometry of each life phase (ANOVA; $\alpha=0.05$ ), except for the relationship PL vs CL for females from Indaiá. The relationship CW vs CL showed a growth pattern similar for males and juvenile females in both studied sites. The relationships that better represented the size at onset of sexual maturity for males were PL vs CL and AW vs CL for females (Table 2).

The size-range indicated by the software Mature I in which $50 \%$ of males from the sampled population are mature, was 4.0 to $6.0 \mathrm{~mm}$ of CL for Indaiá and 3.5 to $5.5 \mathrm{~mm}$ of CL Ubatumirim. In Indaiá, the size at onset of sexual maturity for males of $U$. leptodactyla was estimated at $5.3 \mathrm{~mm}$ of CL, being the size of the smallest mature male $4.5 \mathrm{~mm}$ of CL and the largest immature male $5.9 \mathrm{~mm}$ of CL $(F=67.11 ; \alpha=0.05)$. In Ubatumirim, such size was $4.6 \mathrm{~mm}$ of $\mathrm{CL}$, being the size of the smallest mature male $3.8 \mathrm{~mm}$ and the largest immature male $5.3 \mathrm{~mm}(\mathrm{~F}=89.52$; $\alpha=0.05)$. Thus, concerning both populations we can assume the data were best fitted into two distinct regressions: one for juveniles and the other for adults.

The size at onset of sexual maturity for females from both sites was investigated in ten size-classes. The software Mature I showed $4.1 \mathrm{~mm}$ of CL for $U$. leptodactyla maturity in Indaiá, $3.6 \mathrm{~mm}$ being the size of the smallest adult female and $4.7 \mathrm{~mm}$ the largest juvenile female of CL $(\mathrm{F}=58.88 ; \alpha=0.05)$. With respect to Ubatumirim, the size at onset of sexual maturity was obtained at $4.2 \mathrm{~mm}$ of CL with the smallest mature female measuring $3.7 \mathrm{~mm}$ and the largest immature $5.2 \mathrm{~mm}$ of $\mathrm{CL}(\mathrm{F}=130.49 ; \alpha=0.05)$.

\section{DISCUSSION}

Estuaries are environments daily influenced by physical and chemical oscillations, namely tide and fluvial floods. The similar composition of the sediment and its organic matter content in Indaiá and Ubatumirim sand banks are probably strongly related to their similar hydrology. Temperature, salinity, humidity, photoperiod, texture of the sediment, quantity and availability of food and bottom disturbance are factors which can alter the growth patterns and the size at onset of sexual maturity in crabs in the intertidal estuarine zone.

Colpo \& Negreiros-Fransozo (2003) and von Hagen (1987), who have investigated distinct populations of fiddler crabs, found that growth and maturity were associated with food availability in distinct habitats. Thus, such species show a notable phenotypic plasticity concerning their growth pattern and some aspects of their life cycle, i.e. size at onset of sexual maturity and/or reproductive output. The similar size at sexual morphological maturity in Uca leptodactyla found for both populations can be a consequence of the similarity of environmental resources provided by both habitats, beyond the intrinsic features of the species.

During the brachyuran's ontogeny, alterations in the external body structure appear gradually or sometimes abruptly, mainly in the chelipeds, abdomen and pleopods. Such changes in the secondary sexual characters evidence the sexual transition from the juvenile to the adult phase. The morphological sexual maturity in $U$. leptodactyla showed a similar pattern compared with those obtained for other ocypodid species (Negreiros-Fransozo et al., 2003).

The courtship behaviour of fiddler crabs is predominately visual. The quality and the burrow ornamentation and/or displays exhibited by males with the major cheliped are important attributes for female attraction. Larger males are, probably, best visualized by conspecific females increasing their opportunity to visit their burrows and also to be chosen by them (Zucker, 1986). Such behaviour suggests that male body size and major cheliped interfere in the intra-specific competition. Consequently, when males invest energy in growth, they also tend to maximize the reproductive success of the population. Males of $U$. leptodactyla mature at larger sizes than females in both studied sites, probably because they invest energy to grow while females do it to produce eggs.

The similarity found in the growth pattern of $U$. leptodactyla and other aspects investigated here denote that these populations are regulated by environmental conditions. However, further studies including experimental schedules should be carried out to test whether different organic matter contents will produce distinct growth rates.

To GNPq for a master science fellowship to R.C.F.Cardoso and FAPESP for the financial support to NEBECG Laboratories.

\section{REFERENCES}

Benetti, A.S. \& Negreiros-Fransozo, M.L., 2004. Relative growth of Uca burgersi (Crustacea, Ocypodidae) from two mangroves in the southeastern Brazilian coast. Iheringia, 94, 67-72.

Christy, J.H. \& Salmon, M., 1984. Ecology and evolution of mating system of fiddler crabs (Genus Uca). Biological Reviews, 59, 483-509.

Colpo, K.D. \& Negreiros-Fransozo, M.F., 2003. Reproductive output of Uca vocator (Herbst, 1804) (Brachyura, Ocypodidae) from three subtropical mangroves in Brazil. Crustaceana, 76, 111.

Hagen, H.O. von, 1987. Allometric growth in to populations of Uca tangeri from the Guadalquivir estuary (Andalucia). Investigaciones Pesqueras, 51, 443-452.

Huxley, J.S., 1950. Relative growth and form transformation. Proceedings of the Royal Society of London, 137, 465-469.

Miller, D.C., 1973. Growth in Uca. 1. Ontogeny of asymmetry in Uca pugilator (Bosc) (Decapoda, Ocypodidae). Crustaceana, 24, 119-131.

Negreiros-Fransozo, M.L, Colpo, K.D. \& Costa, T.M., 2003. Allometric growth in the fiddler crab Uca thayeri (Brachyura, Ocypodidae) from a Subtropical mangrove. Fournal of Crustacean Biology, 23, 273-279.

Somerton, D., 1980. A computer technique for estimating the size of sexual maturity in crabs. Canadian Gournal of Fisheries and Aquatic Sciences, 37, 1488-1494.

Zar, J.H., 1996. Biostatistical analysis. Upper Saddler River, New Jersey: Prentice-Hall.

Zucker, W., 1986. On courtship patterns and the size at which male fiddler crabs (Genus Uca) begin to court. Bulletin of Marine Science, 38, 384-388. 